Vol. 1 No. 02 Hal. 91 - 99

September 2018

\title{
Pengaruh Manajemen Berbasis Sekolah dan Metode Pembelajaran Terhadap Motivasi Mengajar Guru di SMP Negeri 1 Tigabinanga
}

\author{
Makmur Sembiring \\ Kepala SMP Negeri 1 Tigabinanga \\ NIP.196711201991031005
}

makmursembiring@gmail.com

\begin{abstract}
ABSTRAK
Penelitian ini bertujuan untuk mengetahui pengaruh manajemen berbasis sekolah dan metode pembelajaran tethadap motivasi mengajar guru di SMP Negeri 1 Tigabinanga. Dalam hal ini adalah untuk mengetahui pengaruh antara manajemen berbasis sekolah dan metode pembelajaran terhadap motivasi mengajar guru. Teknik pengembangunan sampel menggunakan metode sensus dimana wilayah penelitian ini hanya meliputi daerah atau subyek yang sangat sempit. Peneliti merasa perlu untuk meneliti secara keseluruhan tanpa harus mengambil sampel dalam jumlah tertentu yaitu sebesar 35 orang. Hasil penelitian pada SMP Negeri 1 Tigabinanga menunjukkan bahwa variabel manajemen berbasis sekolah dan metode pembelajaran berpengaruh serempak terhadap motivasi mengajar guru. Manajemen berbasis sekolah dan metode pembelajaran secara parsial berpengaruh terhadap motivasi mengajar guru di SMP Negeri 1 Tigabinanga.
\end{abstract}

Kata kunci : manajemen, metode pembelajaran, motivasi belajar

\section{PENDAHULUAN}

Pendidikan merupakan sebuah proses yang sengaja dilaksanakan dengan tujuan untuk mencerdaskan kehidupan bangsa. Melalui proses pendidikan yang baik akan terbentuk sosok individu sebagai sumber daya manusia yang dapat berperan besar dalam proses pembangunan bangsa dan negara. Oleh karena itu peran pendidikan deinikian sangat penting sebab pendidikan merupakan kunci utama untuk menciptakan sumber daya manusia yang utuh dan berkualitas. Undang-Undang Republik Indonesia Nomor 14 Tahun 2005 ayat 1,menyebutkan bahwa: "Guru adalah pendidik profesional dengan tugas utama mendidik, mengajar, membimbing, mengarahkan, melatih, menilai, dan mengevaluasi peserta didik pada pendidikan anak usia dini, jalur pendidikan formal, pendidikan dasar, dan pendidikan menengah". Manajemen Berbasis Sekolah (MBS) adalah model pengelolaan yang memberikan otonoini (kewenangan dan tanggung jawab) lebih besar kepada sekolah, memberikan fleksibilitas/keluwesan- keluwesan kepada sekolah, dan mendorong partisipasi secara langsung warga sekolah (guru, siswa, kepala sekolah, karyawan) dan masyarakat (orang tua, tokoh masyarakat, ilmuwan, pengusaha. dan sebagainya) untuk meningkatkan mutu pendidikan berdasarkan kebijakan pendidikan nasional, serta peraturan perundangan-undangan yang berlaku. Sekolah Memiliki otonomi dan kewenangan yang lebih besar dalam mengelola sekolah, sehingga sekolah lebih mandiri. Mandiri dalam melaksanakan pengelolaan sekolah, pengembangan program-program sekolah yang sesuai dengan keadaan sekolah, juga dalam pengambilan keputusan diputuskan bersama-sama. Sehingga warga sekolah mempunyai rasa Memiliki tanggung jawab dan dedikasi warga sekolah terhadap sekolahnya. Namun demikian Manajemen Berbasis Sekolah (MBS) diharapkan tidak memberi peluang terhadap keinginan individu/ kelompok untuk menguasai sekolah tanpa 
Makmur Sembiring : Pengaruh Manajemen Berbasis Sekolah dan Metode Pembelajaran Terhadap Motivasi Belajar Guru di SMP Negeri 1 Tigabinanga

partisipasi warga sekolah dan masyarakat. Gagasan Manajemen Berbasis Sekolah (MBS) pada dewasa ini menjadi perhatian para pengelola pendidikan, mulai dan tingkat pusat, propinsi, kabupaten/kota sampai dengan tingkat Unit pelaksana teknis daerah (UPTD)/sekolah. Sebagaimana dimakluini, gagasan ini semakin mengemuka setelah dikeluarkannya kebijakan desentralisasi kebijakan pengelolaan pendidikan seperti diisyaratkan oleh UU Nomor 32 Tahun 2004 bahwa dalam menyelenggarakan pemerintahan, Pemerintah menggunakan asas desentralisasi, tugas pembantuan, dan dekosentrasi sesuai dengan peraturan perundang-undangan. Manajemen Berbasis Sekolah (MBS) adalah model manajemen yang memberikan manajemen lebih besar kepada sekolah untuk lebih bertanggung jawab terhadap mutu peserta didik yaitu melalui peningkatan motivasi mengajar tenaga pendidik di sekolah yang bersangkutan. Manajemen Berbasis Sekolah (MBS) secara tidak langsung mengharuskan kepala sekolah untuk lebih berpartisipasi dalam setiap kegiatan/upaya yang dilakukan untuk meningkatkan kualitas pendidikan seperti penentuan metode pembelajaran yang digunakan guru dalam mengajar. Selain Manajemen berbasis Sekolah, Metode pembelajaran juga sangat menentukan keberhasilan anak didik dalam menuntut ilmu. Metode sebagai cara atau jalan yang harus dilalui untuk mencapai suatu tujuan tertentu. Penguasaan substansi tidaklah cukup, jika metode yang dipakai tidak tepat. Hal ini merupakan salah satu usaha yang tidak boleh ditinggalkan oleh tenaga pendidik adalah bagaimana memahaini kedudukan metode sebagai salah satu komponen yang ikut ambil bagian bagi keberhasilan kegiatan pembelajaran. Guru sebagai tenaga pendidik diharapkan mampu mengelola seluruh proses kegiatan belajar-mengajar secara efektif. Untuk itu guru harus Memiliki pengetahuan yang cukup tentang prinsip-prinsip belajar sebagai dasar dalam merancang kegiatan belajarmengajar, salah satunya adalah tentang memilih metode yang tepat dalam proses pembelajaran. Metode pembelajaran yang dapat digunakan seperti Metode pembelajaran diskusi, demonstrasi, resitasi, eksperimental, serta metode latihan keterampilan. Tujuan utama dari hal tersebut adalah untuk mengembangkan prosedur kebijakan sekolah, memecahkan masalah-masalah umum, memanfaatkan semua potensi individu yang tergabung dalam tim tersebut sehingga dapat meningkatkan motivasi mengajar guru yang nantinya dapat mencerdaskan pelajar, yang mempunyai emosional tinggi, serta juga dapat mempersiapkan tenaga-tenaga pembangunan. Guru harus mampu memainkan perannya sebaik mungkin, sebagimana telah dinyatakan oleh Slameto, yang dikutip oleh Usman (2006) bahwa salah satu sikap profesionalisme guru adalah Memiliki semangat untuk memberikan layanan kepada siswa, sekolah dan masyarakat. Dengan deinikian motivasi mengajar merupakan penggerak perilaku yang bersifat diriainis, majemuk dan spesifik bagi guru sebagai pengajar. Sebagaimana telah diketahui urusan pendidikan telah disentralisasikan dan diotonomikan dari pemerintah pusat kepada pemerintah daerah kabupaten/kota hal ini sejalan dengan adanya perubahan paradigma sistem pemerintah yakni pemerintah telah menyerahkan urusan kewenangan pemerintahan pusat kepada pemerintahan daerah kabupaten/kota. Dalam hal ini urusan pendidikan yang telah diserahkan kepada pemenintahan kabupaten/kota bahkan sampai kepada tingkat satuan pendidikan yang dikenal Manajemen Berbasis Sekolah (MBS). Kini satuan pendidikan SMP Negeri 1 Tigabinanga bertanggung jawab untuk meningkatkan mutu pembelajaran siswa dalam kerangka Manajemen Berbasis Sekolah (MBS). Situasi yang terjadi di SMP Negeri 1 Tigabinanga menggambarkan bahwa guru yang kurang termotivasi dalam mengajar. Hal ini dapat dilihat dan kurang semangat ketika mengajar seolah-olah menjadi beban sehingga terkesan tidak keseriusan dalam mengajar, disamping itu guru jarang memberikan tugas dan kurang memotivasi kepada siswa untuk belajar kembali dirumah. Selain itu, beberapa guru ditemukan sering terlambat dalam menyelesaikan tugas yang 
diberikan oleh kepala sekolah, seperti evaluasi proses belajar mengajar. Hal tersebut dapat dipengaruhi oleh beberapa faktor diantaranya penerapan Manajemen Berbasis Sekolah dan Metode Pembelajaran. Dan situasi yang dipaparkan diatas, hal tersebut dapat disebabkan oleh penerapan MBS yang belum optimal sehingga belum dapat mencapai apa yang menjadi tujuan dan penerapan MBS itu sendiri. Penerapan MBS disini dilaksanakan oleh kepala sekolah yang bersangkutan. oleh karena itu, kebijakan yang ditetapkan oleh kepala sekolah menjadi penentu keberhasilan dalam penerapan MBS di SMP Negeri 1 Tigabinanga. Selanjutnya metode pembelajaran juga dapat mempengaruhi motivasi dalam mengajar. Kondisi yang terlihat disini yaitu metode pembelajaran yang diterapkan oleh guru terkesan kaku atau dapat dikatakan tidak variatif. Hal inilah yang diduga menjadi salah satu faktor penyebab kurangnya motivasi mengajar guru di SMP Negeri 1 Tigabinanga. Hal ini tidak boleh kesampingkan begitu saja, karena dapat berdampak baik secara langsung maupun tidak langsung pada keberhasilan suatu sekolah.

\section{METODE PENELITIAN}

Langkah-langkah yang dalam penelitian ini adalah sebagai berikut:

\section{Mengumpulkan Data}

Teknik pengumpulan data yang digunakan dalam penelitian ini adalah:

1. Wawancara

Wawancara merupakan teknik pengumpulan data yang dilakukan melalui tatap muka dan tanya jawab langsung antara pengumpul data maupun peneliti terhadap tiara sumber atau sumber data.

2. Kuesioner

Kuesioner yaitu suatu metode dimana peneliti menyusun daftar pertanyaan secara tertulis yang kemudian dibagikan kepada responden untuk memperoleh data yang berhubungan dengan kegiatan penelitian.

3. Studi kepustakaan

Pengumpulan data yang berasal dan beberapa literatur serta bacaan lain yang mendukung penelitian ini.

\section{Menentukan Jenis Penelitian, Populasi dan Sampel}

Penelitian ini bermaksud untuk menguji hipotesis dengan harapan membenarkan atau memperkuat dugaan yang telah dirumuskan yang pada gilirannya dapat mendukung teori. Atas dasar asumsi tersebut, maka jenis penelitian yang digunakan termasuk explanatory research melalui penelitian asosiatif, yaitu penelitian yang bertujuan untuk menjelaskan hubungan antara dua variabel atau lebih (Sugiyono, 2005). Dalam hal ini adalah untuk mengetahui pengaruh antara manajemen berbasis sekolah dan metode pembelajaran terhadap motivasi mengajar. Populasi adalah wilayah generalisasi yang terdiri atas obyeklsubyek yang mempunyai kualitas dan karakteristik tertentu yang ditetapkan oleh peneliti untuk dipelajari dan kemudian ditarik kesimpulannya (Sugiyono, 2005). Dalam penelitian ini yang menjadi populasinya adalah seluruh guru di SMP Negeri 1 Tigabinanga. Melihat jumlah populasi hanya sebesar 35 orang, maka layak untuk diambil semua untuk dijadikan sebagai sampel sehingga penelitian ini merupakan penelitian sensus. Pengambilan sampel yang digunakan adalah metode sensus, hal itu karena ditinjau dan wilayahnya penelitian ini hanya meliputi daerah atau subyek yang sangat sempit. Sehingga peneliti merasa perlu untuk meneliti secara keseluruhan tanpa harus mengambil sampel dalam jumlah tertentu 
Makmur Sembiring : Pengaruh Manajemen Berbasis Sekolah dan Metode Pembelajaran Terhadap Motivasi Belajar Guru di SMP Negeri 1 Tigabinanga

\section{Teknik Analisis Data}

Dalam penelitian ini, teknik analisis data dilakukan sebagai berikut:

\section{Uji Normalitas}

Uji normalitas bertujuan untuk menguji apakah dalam data, variabel terikat dengan variabel bebas keduanya mempunyai hubungan distribusi normal atau tidak. Data yang baik adalah Memiliki distribusi data normal atau mendekati normal (Ghozali, 2007). Uji Normalitas data yang digunakan dalam penelitian adalah Analisis Statistik. Analisis statistik digunakan mendeteksi normalitas dalam penelitian ini dilakukan dengan uji Kolmogorof Sinirnov. Untuk mengetahui apakah data tersebut berdistribusi normal, maka dapat dilihat dengan Kolmogorov Sinirnov Test. Adapun kriterianya adalah:

- Angka signifikansi (SIG) $>0,05$, maka data berdistribusi normal

- Angka signifikansi (SIG) <0,05, maka data tidak berdistribusi normal

\section{Uji Multikolinearitas}

Multikolinieritas berarti bahwa antara variabel bebas yang satu dengan variabel bebas yang lain dalam model regresi saling berkorelasi linear. Uji ini bertujuan untuk menguji apakah model regresi ditemukan adanya korelasi antar variabel bebas (independen). Model regresi yang balk seharusnya tidak terjadi korelasi diantara variabel bebas. Jika variabel bebas sating berkorelasi, maka variabel-variabel ini tidak ortogonal. Variabel ortogonal adalah variabel bebas yang nilai korelasi antar sesama variabel bebas sama dengan nol. Apabila terjadi multikolinieritas maka variabel bebas yang berkolinier dapat dihilangkan. Untuk mengetahui ada tidaknya multikolinear menurut perhitungan yang dilakukan program SPSS dengan berpedoman bahwa multikolinieritas dapat dilihat dan nilai tolerance-nya dan lawannya variance inflation factor (VIF). Nilai tolerance yang rendah sama dengan nilai VIF tinggi dan menunjukkan kolinieritas yang tinggi. Nilai cutoff bagi angka tolerance adalah sebesar 0,10 atau sama dengan nilai VIF diatas 10, artinya bahwa semua variabel yang akan dimasukkan dalam perhitungan model regresi harus mempunyal tolerance di atas 0,10. Jika Iebih rendah dan dan 0,10 maka terjadi multikolinearitas. Sedangkan hasil perhitungan nilal VTF, jika Memiliki nilai VIF kurang dan 10, maka tidak mempunyai persoalan multikolinieritas.

\section{Uji Heteroskedastisitas}

Heteroskedastisitas berarti varians (variasi) variabel tidak sama untuk semua pengamatan. Uji heterokedastisitas bertujuan menguji apakah dalam model regresi terjadi ketidaksamaan variance dan residual satu pengamatan ke pengamatan yang lain tetap, maka disebut homoskedastisitas dan jika berbeda disebut heterokedastisitas. Model regresi yang baik adalah yang homoskedastisitas atau terjadi heterokedastisitas. Kebanyakan data cross section mengandung situasi heterokedastisitas karena data ini menghimpun data yang mewakili berbagai ukuran (kecil!, sedang dan besar). Ada beberapa cara untuk mendeteksi ada atau tidaknya heterokedastisitas, salah satunya dengan melihat grafik plot antara nilai prediksi variabel terikat (ZPRED) dengan residualnya (ZRESID). Deteksi ada tidaknya heterokedastisitas dapat dilakukan dengan melihat ada tidaknya pola tertentu pada grafik scatterplot antara ZRESID dan ZPRED dimana sumbu Y adalah Y yang telah diprediksi, dan sumbu $\mathrm{X}$ adalah residual ( $\mathrm{Y}$ prediksi $-\mathrm{Y}$ sesunggulinya) yang telah distudentized. Dasar analisis:

- Jika ada pola tertentu, seperti titik-titik yang ada membentuk pola tertentu yang teratur (bergelombang, melebar kemudian menyempit), maka mengindikasikan telah terjadi heteroskedastisitas.

- tidak ada pola yang jelas, serta titik-titik menyebar diatas dan di bawah angka 0 pada sumbu Y, maka tidak terjadi heteroskedastisitas 
Makmur Sembiring : Pengaruh Manajemen Berbasis Sekolah dan Metode Pembelajaran Terhadap Motivasi Belajar Guru di SMP Negeri 1 Tigabinanga

\section{Analisis Linear Berganda}

Untuk mengetauhi adanya pengaruh antara Manajemen Berbasis Sekolah (X1), dan Metode Pembelajaran (X2) terhadap motivasi mengajar (Y), digunakan metode analisis regresif berganda yang dibantu dengan program SPSS dalam pengolahanya, Rumus yang digunakan adalah sebagai berikut :

$$
\mathrm{Y}=\mathrm{a}+\mathrm{b}_{1} \mathrm{X}_{1}+\mathrm{b}_{2} \mathrm{X}_{2}+\mathrm{e}
$$

Ketarangan :

a $\quad=$ Konstanta

$\mathrm{b} \quad=$ Koefisien regresi berganda

$\mathrm{Y}=$ Motivasi mengajar

$\mathrm{X}_{1} \quad=$ Manajemen Berbasis sekolah

$\mathrm{X}_{2} \quad=$ Metode Pembelajaran

e $\quad=$ error of term (variabel pengganggu)

\section{Uji Statistik}

\section{a. Uji Parsial (uji t)}

yaitu suatu uji untuk mengetahui pengaruh variabel bebas terhadap variabel terikat secara parsial, dengan menggunakan langkah sebagai berikut :

1. Menentukan hipotesis

Ho : $\beta=0$ Tidak terdapat pengaruh yang signifikan antara variabel bebas terhadap variabel terikat

Ha : $\beta=0$ Terdapat pengaruh yang signifikan antara variabel bebas terhadap variabel terikat

2. Kesimpulan

a. Jika t hitung $>\mathrm{t}$ tabel dan $\mathrm{L}$ hitung $<\mathrm{L}$ tabel maka Ho ditolak dan Ha diterima Artinya ada pengaruh antara variabel bebas secara parsial terhadap variabel terikat. Dengan demikian hipotesis dapat diterima/terbukti.

b. Jika $t$ hitung $<\mathrm{t}$ tabel dan $\mathrm{L}$ hitung $>\mathrm{L}$ tabel maka Ho diterima dan Ha ditolak. Artinya tidak ada pengaruh antara variabel bebas secara parsial terhadap variabel terikat. Dengan demiian hipotesis ditolak/tidak terbukti

\section{b. Uji Serempak (uji f)}

Yaitu digunakan untuk menguji dan mengetahui apakah variabel independen berpengaruh secara serempak terhadap variabel independen atau tidak. Uji $\mathrm{F}$ dapat dilihat dari nilai Hitung F dengan ketentuan sebagai berikut :

1. Jika $\mathrm{F}$ hitung $>\mathrm{F}$ tabel dan nilai signifikasinya $<0,05$ maka ada pengaruh serempak antara variabel bebas terhadap variabel terikat. Dengan demikian hipotesis diterima

2. Jika $F$ hitung $<F$ tabel dan nilai signifikasinya $>0,05$ maka tidak ada pengaruh serempak antara variabel bebas terhadap variabel terikat. Dengan demikian hipotesis ditolak.

\section{HASIL PENELITIAN}

Berdasarkan data yang terkumpul dari hasil analisis statistik, maka ketiga hipotesis yang dikemukakan diterima. Hipotesis pertama (H1) diterima berarti bahwa Manajemen Berbasis Sekolah secara parsial berpengaruh signifikan terhadap motivasi mengajar guru di SMP Negeri 1 Tigabinanga, hal tersebut dapat dilihat dari $t_{\text {hitung }}$ yang diperoleh sebesar 2,389 dengan tingkat signifikasi 0,023 . Jika dibandingkan dengan $t_{\text {tabel }}$ pada tingkat kepercayaan 0,05 yang besarnya 2,032 maka nilai $t_{\text {hitung }}(2,389)>t_{\text {tabel }}(2,011)$ bahwa 
Makmur Sembiring : Pengaruh Manajemen Berbasis Sekolah dan Metode Pembelajaran Terhadap Motivasi Belajar Guru di SMP Negeri 1 Tigabinanga

Penerapan Manajemen Berbasis Sekolah adalah merupakan salah satu faktor yang dapat mempengaruhi motivasi mengajar guru. Hasil kuesioner menunjukkan bahwa responden (guru) menyatakan bahwa kepala sekolah Memiliki peran yang kuat dalam mengkoordlnasikan, menggerakan dan menyerasikan semua sumber daya pendidikan yang tersedia. Sumber daya disini seperti guru, staff, siswa, sarana dan prasarana. Sekolah efektif dalam perspektif manajemen, bahwa sekolah merupakan proses pemanfaatan seluruh sumber daya sekolah yang dilakukan melalui tindakan yang rasional dan sistematik (mencakup perencanaan, pengorganisasian, penggerakan tindakan dan pengawasan) untuk mencapai tujuan sekolah secara efektif dan efisien termasuk di dalamnya motivasi guru untuk mengajar dengan hasil yang lebih baik. Hipotesis kedua (112) diterima berarti bahwa metode pembelajaran secara parsial berpengaruh signifikan terhadap motivasi mengajar guru di SMP Negeri 1 Tigabinanga, hal tersebut dapat dilihat dan $t_{\text {hitung }}$ yang diperoleh sebesar 2,137 dengan tingkat signifikansi 0,040a. Jika dibandirigkan dengan tti pada tingkat kepercayaan $0,05^{\mathrm{a}}$ yang besarnya 2,032 , maka nilai $t_{\text {hitung }}(2,137)>\mathrm{t}_{\text {tabel }}(2,032)$. Responden menyatakan bahwa sarana dan prasarana yang digunakan untuk mendukung proses belajar-mengajar sudah memadai, selain itu di SMP Negeri 1 Tigabinanga sudah menggunakan media baik yang berbasis audio maupun visual serta menggunakan multimedia berbasis komputer dan inter-active video. Untuk mengetahui adanya pengaruh antara Manajemen Berbasis Sekolah(X1) Metode Pembelajaran (X2) terhadap motivasi mengajar (Y), digunakan metode analisis regresi berganda yang dibantu dengan program SPSS dalam pengolahannya. Berdasarkan hasil pengolahan data, diperoleh data berikut:

Tabel Analisis Regresi Linear Berganda

\begin{tabular}{|c|c|c|c|}
\hline \multirow{2}{*}{\multicolumn{2}{|c|}{ Model }} & \multicolumn{2}{|c|}{$\begin{array}{c}\text { Unstandardized } \\
\text { Coefficients }\end{array}$} \\
\hline & & B & Std. Error \\
\hline & (Constant) & 2.064 & .516 \\
\hline & Manajemen_Berbasis_Sekolah & .317 & .133 \\
\hline & Metode Pembelajaran & .289 & .135 \\
\hline
\end{tabular}

Persamaan regresi yang diperoleh dan kedua variabel dependen ini adalah $\mathrm{V}=2,064+$ $0,317 \mathrm{X} 1+0,289 \mathrm{X} 2$. Persamaan linear dapat menjelaskan bahwa apabila tidak terdapat pengaruh dan variabel dependen, maka motivasi mengajar sebesar 2,064. Koefisien regresi Manajernen Berbasis Sekolah menunjukkan makna positif terhadap motivasi mengajar. Hal ini berarti bahwa jika Manajemen Berbasis Sekolah meningkat sebesar 1 (satu) satuan maka motivasi mengajar akan meningkat sebesar 0,317 satuan. Sebaliknya jika Manajemen Berbasis Sekolah menurun sebesar 1 (satu) satuan maka motivasi mengajar akan menurun sebesar 0,324 satuan. Koefisien regresi model pembelajaran menunjukkan makna positif terhadap motivasi mengajar. Hal ini berarti bahwa jika metode pembelajaran meningkat sebesar 1 (satu) satuan maka motivasi mengajar akan meningkat sebesar 0,310 satuan. Sebaliknya jika metode pembelajaran menurun sebesar I (satu) satuan maka motivasi mengajar akan menurun sebesar 0,310 satuan. Dengan adanya berbagai metode pembelajaran menggunakan media, bukan hanya siswa yang lebih semangat dalam belajar, melainkan guru juga akan lebih merasa variatif dalam mengajar, sehingga mereka akan termotivasi dalam menciptakan kreatifitas dalam mengajar dengan memanfaatkan media tersebut, yang pada akhimya akan memotivasi untuk mengajar lebih baik. Hipotesis ketiga (H3) diterima berarti bahwa Manajemen Berbasis Sekolah dan metode pembelajaran secara 
serempak berpengaruh signifikan terhadap motivasi mengajar guru di SMP Negeri 1 Tigabinanga, hal tersebut dapat dilihat dan $F_{\text {hitung }}$ yang diperoleh sebesar 12,460 dengan tingkat signifikansi $0,000^{\mathrm{a}}$. Jika dibandingkan dengan ti pada tingkat kepercayaan $0,05 \mathrm{a}$ yang besarnya 1,84 , maka nilai Fiug $(12,460)>$ Fini $(1,84)$.

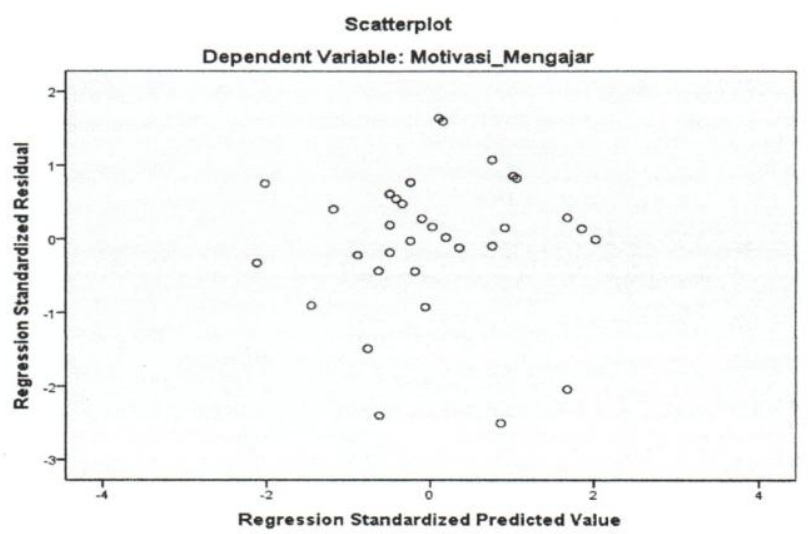

Gambar Grafik Plot Scatter plot

Hasil deskripsi statistik menunjukkan bahwa di SMP Negeri 1 Tigabinanga, Kepala Sekolah Memiliki peran yang kuat dalam mengkoordiriasikan dan menyerasikan semua sumber daya pendidikan yang tersedia, kemudian juga didukung oleh pengembangan dalam pengelolaan tenaga kependidikan (guru) yang dilakukan secara efektif. Dalam menjalankan tugasnya, terdapat Team Work yang Kompak, Cerdas, dan Diriainis Kebersamaan baik antar guru, guru dengan kepala sekolah, maupun guru dengan staff. Disamping itu, Pihak sekolah melakukan evaluasi dan perbaikan secara berkelanjutan serta selalu tanggap terhadap berbagai aspirasi yang muncul bagi peningkatan mutu. Hal tersebut menjadi pendorong meningkatnya motivasi mengajar guru di SMP Negeri 1 Tigabinanga. Besamya total kontribusi variabel Manajemen Berbasis Sekolah dan metode pembelajaran terhadap motivasi mengajar guru SMP Negeri 1 Tigabinanga mencapai 40,3\%, sedangkan sisanya sebesar $59,7 \%$ diperkirakan bahwa motivasi mengajar dipengaruhi oleh variabel lain yang tidak diteliti dalam penelitian ini.

\section{KESIMPULAN}

Berdasarkan uraian penelitian diatas maka dapat diambil beberapa kesimpulan, yaitu:

1. Hasil analisis statistik, menunjukkan bahwa Manajemen Berbasis Sekolah secara parsial berpengaruh terhadap motivasi mengajar guru SMP Negeri 1 Tigabinanga.

2. Hasil analisis statistik, menunjukkan bahwa Metode Pembelajaran secara parsial berpengaruh terhadap motivasi mengajar guru SMP Negeri 1 Tigabinanga.

3. Hasil analisis statistik, menunjukkan bahwa Manajemen Berbasis Sekolah dan metode pembelajaran secara serempak berpengaruh terhadap motivasi mengajar guru SMP Negeri 1 Tigabinanga.

4. Variabel Manajemen Berbasis Sekolah dan metode pembelajaran memberikan kontribusi sebesar 40,3\% terhadap motivasi mengajar guru SMP Negeri 1 Tigabinanga, sedangkan sisanya sebesar 59,7\% diperkirakan dan variabel lain yang tidak diteliti dalam penelitian ini. 
Makmur Sembiring : Pengaruh Manajemen Berbasis Sekolah dan Metode Pembelajaran Terhadap Motivasi Belajar Guru di SMP Negeri 1 Tigabinanga

\section{SARAN}

Adapun saran yang dapat diberikan oleh peneliti, adalah sebagai berikut:

1. Kepala Sekolah SMP Negeri 1 Tigabinanga

Dalam menerapkan MBS, kepala sekolah harus Memiliki kebijakan, tujuan dan sasaran mutu yang jelas dan mengontrol ketersedianya sumberdaya yang kompetitif dan berdedikasi. Kepala sekolah juga harus Memiliki kepemimpinan yang kuat,membuat tim kerja yang kompak dan dinainis, serta harus mengelola tenaga kependidikan dengan efektif guna mencapai efektifitas yang tinggi dalam proses belajar mengajar. Selain itu, kepala sekolah harus partisipatif dan keterbukaan (transparansi) dalam pengelolaan sekolah.

2. Para guru hendaknya menguasai metode pembelajaran yang digunakan, seperti penggunaan media atau metode lainnya dengan cara mengadakan kegiatan-kegiatan mengenai peningkatan pemanfaatan media belajar selanjutnya dievaluasi secara berkelanjutan.

3. Guru seharusnya mampu menguasai penggunaan media pengajaran, sehingga pengajaran lebih bervariatif guna menghindari kekakuan seth kejenuhan baik dan siswa maupun guru sendiri.

4. Bagi peneliti selanjutnya disarankan unutk meneliti variabel lain yang mempengaruhi motivasi mengajar guru, seperti gaya kepemimpinan, lingkungan kerja, budaya organisasi, dan lain-lain

\section{DAFTAR PUSTAKA}

Arikunto, Suharsiini. 2007. Manajemen penelitian. Jakarta Rineka Cipta.

Depdiknas. 2007. Manajemen Berbasis Sekolah. Jakarta: Dirjen Manajemen.

Dimyati dan Mudjiono, 2006. Belajar dan Pembelajaran, Jakarta: Rineka Cipta

Djamarah, Syaiflil Bahri. 2007. Strategi Belajar Mengajar. Jakarta:Rineka Cipta.

Ghozali, Imam. 2007. Aplikasi Analisis Multivariate dengan Program SPSS. Semarang : Penerbit Universitas Diponegoro.

Hasibuan, Malayu, SP . 2005. Manajemen Sumber Daya Manusia, Jakarta: PT. Buini Aksara.

Ibrahim, Bafadal, 2006. Manajemen Peningkatan Mutu Sekolah Dasar dan Sentralisasi Menuju Desentralisasi. Jakarta: Buini Aksara.

Ismail, Hanif dan Darsono Prawironegoro. 2009. Sistem pengendalian Manajemen, Konsep dan Apliki.sinya. Jakarta. Initra Wacana Media.

Mangkunegara, Anwar Prabu. 2009. Evaluasi Kinerja Sumber Daya Man usia, Bandung Refika Aditama.

Minarti, Sri. 2011. Manajemen Sekolah : Mengelola Lembaga Pendidikan Secara Mandiri. Yogyakarta : Ar-Ruzz Media. 
Makmur Sembiring : Pengaruh Manajemen Berbasis Sekolah dan Metode Pembelajaran Terhadap Motivasi Belajar Guru di SMP Negeri 1 Tigabinanga

Mulyasa, E. 2009. Manajemen Berbasis Sekolah Konsep, Strategi., dan Implementasi. Bandung: Remaja Rosdakarya.

Purwanto, Ngalim. 2006. Adiriinistrasi dan supervisi pendidikan. Bandung: PT Remaja Rosdakarya.

Robbins, Stephen P. Judge, Timothy A. 2008. Perilaku Organisasi Buku 1, Jakarta: Salemba Empat.

Riduwan. 2009, Metode dan Teknik Menyusun Tesis, Bandung: Alfabeta.

Saefullah, Sule, Ernie Tisnawati dan Kurniawan. 2010. Pengantar Manajemen. Edisi Pe tama. Cetakan Kelima. Jakarta. Kencana.

Siswanto, Bedjo. 2005. Pengantar Manajemen. Jakarta: Buini Aksara.

Slameto, Dkk. 2009. Manajemen Berbasis Sekolah . Ditjen Dikti. Depdiknas

Sudjana, Nana. 2005. Dasar-Dasar Proses Belajar Mengajar. Bandung: Sinar Baru Algesindo..

Suparlan. 2013. Manajemen berbasis sekolah (MBS): dan teoni sampai dengan praktik. Jakarta: Buini Aksara.

Sugiyono. 2005. Metode Penelitian Bisñis. Bandung : Penerbit Alfabeta.

Sulistiyani, Ambar Teguh dan Rosidah. 2009. Manajemen Sumber Daya Manusia. Konsep, Teori dan Pengembangan Dalam Konteks Organisasi Publik. Cetakan Pertama. Yogyakarta : Graha Ilmu.

Suryani, Tatik. 2008. Penilaku Konyumen: Implikasi pada Strategi Pemasaran, Edisi 1. Yogyakarta: Graha Ilmu.

Sutikno, M. Sobry dan Pupuh Fathur Rohman . 2009. Strategi Belajar Mengajar Me!alui Penanaman Konsep Umum Dan Konsep Islaini, Bandung: PT Rafika Adi tama.

Usman. 2006. Manajemen Teoni, Praktik dan Riset Pendidikan. Jakarta: PT. Buini Akasara

Usmara. 2006. Motivasi Kerja. Proses, Teori dan Praktek. Cetakan Pertama. Yogyakarta: Amara Books. 